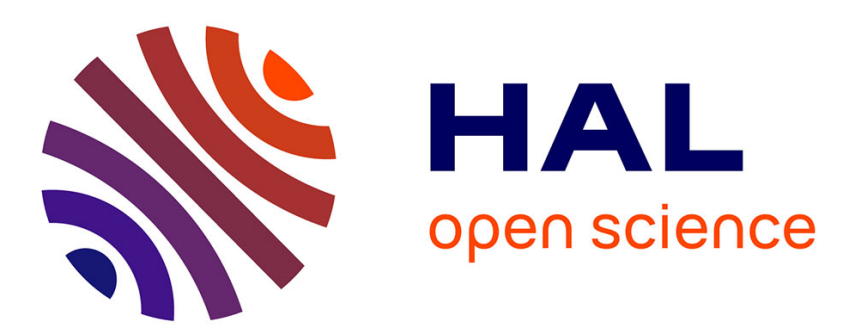

\title{
Origin of zircon megacrysts in alkaline lavas (French Massif Central): Petrology and in situ U-Pb-Hf isotopes
}

\author{
Jean-Louis Paquette, Gilles Chazot, Abdelmouhcine Gannoun
}

\section{To cite this version:}

Jean-Louis Paquette, Gilles Chazot, Abdelmouhcine Gannoun. Origin of zircon megacrysts in alkaline lavas (French Massif Central): Petrology and in situ U-Pb-Hf isotopes. Journal of Volcanology and Geothermal Research, 2020, 399, pp.106907. 10.1016/j.jvolgeores.2020.106907 . hal-02792848

\section{HAL Id: hal-02792848 \\ https://hal.uca.fr/hal-02792848}

Submitted on 5 Jun 2020

HAL is a multi-disciplinary open access archive for the deposit and dissemination of scientific research documents, whether they are published or not. The documents may come from teaching and research institutions in France or abroad, or from public or private research centers.
L'archive ouverte pluridisciplinaire HAL, est destinée au dépôt et à la diffusion de documents scientifiques de niveau recherche, publiés ou non, émanant des établissements d'enseignement et de recherche français ou étrangers, des laboratoires publics ou privés. 
1 Origin of zircon megacrysts in alkaline lavas (French Massif Central): petrology and in situ U-Pb-Hf isotopes.

${ }^{1}$ Laboratoire Magmas \& Volcans, Clermont Université, UCA - CNRS - IRD, 6 avenue Blaise Pascal, F-63000 Clermont-Ferrand, France.

${ }^{2}$ Institut Universitaire Européen de la Mer, CNRS UMR6538, Université de Bretagne 11 Occidentale, Place Copernic, F-29280 Plouzané, France.

Keywords: U-Pb zircon dating; Hf isotopes; alkali basalts; Pliocene volcanism; lithospheric mantle; lower continental crust; French Massif Central.

\section{Abstract}

In the south eastern Devès volcanic domain of the French Massif Central, we sampled red zircon megacrysts in, both, alluvium from a small stream and neighbouring mugearite lava. LA-ICP-MS U-Pb dating results yield similar ages for both suites of zircons at about 2.6 Ma. Superchondritic signatures of the Hf isotopes clearly indicate a depleted mantle source for these zircons.

The mugearite lava also contains xenoliths of mantle (lherzolites) and lower crustal rocks (granulites). The chemical compositions of the minerals within the mugearite lava are 
similar to the mineral compositions found in these xenoliths (granulites) and granulite and peridotite xenoliths from other volcanic localities of the Massif Central. The mugearite lava also preserves Variscan zircon crystals dated at $285 \mathrm{Ma}$, originating from recycled lower continental crust.

In spite of their mantle origin, as recorded by in situ Hf isotopes, the geochemistry suggests that these Pliocene zircons do not result from crystallization in the mantle or in mantle-derived mafic magmas. In order to explain this inconsistency, we propose that these zircon grains crystallized from felsic melts produced during the ultimate differentiation of mantle-derived mafic magmas in the mid or upper continental crust. Subsequently, a last basaltic batch forced its way to the surface, scavenging upper mantle and lower crust xenoliths as well as zircon xenocrysts formed in these felsic melts which partly dissolved during their ascent.

Large amounts of Cenozoic zircon megacrysts are often associated with sapphires in alluvial deposits in many continental volcanic domains, not only in the French Massif Central but also worldwide. Consequently, a huge volume of felsic differentiates issued from mantlederived basaltic magmas might be suspected in many alkaline volcanic domains at the global scale.

\section{Introduction} this mineral in basalts is unlikely (Watson, 1979; Watson and Harrison, 1983) since several percent of $\mathrm{ZrO}_{2}$ content may be dissolved in the melt at about $1300^{\circ} \mathrm{C}$ before any crystallisation of zircon (Guo et al., 1996). Consequently, primary crystallisation of zircon in most mafic volcanic melts is rare. Nevertheless, large amounts of zircons and sometimes 
zircon megacrysts are exposed in alluvial deposits located in the vicinity of large mafic lava flows or occur directly within the volcanic rocks. The presence of zircon, sometimes associated with sapphire, is reported in many alkali basalt fields worldwide (see reviews in Guo et al., 1996; Pin et al., 2006; Simonet, 2000; Sutherland and Fanning, 2001; Sutherland et al., 1998, 2002 and 2008; Upton et al., 1999; Sutthirat et al., 2020 and reference therein). In addition, these rocks frequently include xenolithic enclaves and minerals (Upton et al., 1999; Paquette and Mergoil-Daniel, 2009; Hurai et al., 2010 and 2013; Rakotosaminazanany et al., 2014; Huraiova et al., 2017). It is generally agreed that zircons found in basaltic rocks must be "exotic minerals" to their mafic hosts, but the origin of these zircon crystals is still debated. They can be derived from differentiated newly-formed magmas emplaced at mantle and/or crustal depth or may be xenocrysts of ancient continental basement carried upwards during the eruption. Constraining their origin is the major goal of this contribution. Zircon megacrysts mostly occur in placers linked to alkali basalt environments in numerous continental volcanic fields around the world. We focus our study in the Velay volcanic province in the south eastern Massif Central in France. This domain is characterized by the occurrence of both zircon gems in sedimentary deposits near the basaltic fields and of zircon crystals directly hosted in alkaline lavas. This area is well known for the size and the abundance of zircon (and sapphire) gems collected since the Middle Ages (Lacroix, 1901). We sampled zircon from both the sedimentary deposits and the lavas in the same volcanic field. The petrography and geochemistry of the lavas and their exotic accessory minerals, and the determination of $\mathrm{U}-\mathrm{Pb}$ ages and $\mathrm{Hf}$ isotopes of the zircons by in situ LA-(MC)-ICP-MS, were investigated in order to constrain their age and origin.

\section{Geological setting}


The volcanism in the French Massif Central forms a significant part of the Neogene peri-Alpine intra-continental volcanism. Several large and distinct recent volcanic domains are located in the central and eastern parts of the French Massif Central (Wilson and Downes, 1991). Among them, the Velay is a well-individualised entity, where a succession of volcanic eruptions of various types overlies the Variscan continental basement (Fig. 1). The eastern part of the Velay domain is composed of basalts and more differentiated rocks ranging from mugearites and benmoreites to trachytes and phonolites (Willemant et Treuil, 1983; Dautria et al., 2004). Some rare carbonatite lavas are also present (Chazot et al., 2003). The age of this volcanic activity ranges from $14 \mathrm{Ma}$ to $6.5 \mathrm{Ma}$. In the western part, the Devès province is characterized by abundant mafic lavas forming a large volcanic plateau, mostly emplaced between $6 \mathrm{Ma}$ and 0.6 Ma. The magmas belong to an alkaline series and the differentiated rocks are either silica saturated or undersaturated. The studied samples were collected from the north eastern margin of the Devès plateau (the Puy-en-Velay graben). A detailed geological study of the Velay volcanism can be found in Mergoil and Boivin (1993).

The zircon-bearing rocks and the zircon gems from fluviatile deposits were both sampled in a narrow zone of few kilometres centred on the Mount Croustet volcano. Mafic rocks containing visible zircon crystals were sampled at or near the "Les Brus" quarry. The zircon gems come from the neighbouring "Les Brus" streams. Very precise locations of the outcrops including detailed maps are provided in Carbonnel and Robin (1972) and Forestier (1993).

\section{Petrology and geochemistry of the host rock}

The studied sample has a porphyritic microlithic texture. The groundmass is mostly made of plagioclase and Fe-Ti oxides with altered glass. Microphenocrysts of clinopyroxene 
and phenocrysts of amphibole are abundant. These latter are totally weathered but easily recognisable from their characteristic shape.

Many xenoliths and xenocrysts are also present in this rock. Large garnets (up to 1.2

$104 \mathrm{~cm}$ long) contain quartz, clinopyroxene and plagioclase inclusions. They are surrounded by

105 a reaction corona at the contact with the host magma. Granulite xenoliths can be up to $2 \mathrm{~cm}$

106 long and contain quartz, orthopyroxene, clinopyroxene, plagioclase, biotite, oxide and

107 carbonate. Some small and rounded zircons are also present. Some of these xenoliths have 108 been partially disintegrated into the magma, and all their minerals are present as xenocrysts 109 in the rock sample.

110 Despite large amounts of xenoliths and xenocrysts, whole rock analysis of the studied sample 111 indicates a mugearitic composition (Table 1), with 51.2 wt. \% of $\mathrm{SiO}_{2}$ and only 3.6 wt. \% of $112 \mathrm{MgO}$. It is alkali-rich, with $\mathrm{Na}_{2} \mathrm{O}+\mathrm{K}_{2} \mathrm{O}=8.2$ wt. \%. The rock is enriched in light rare earth 113 elements, with La content of $88 \mathrm{ppm}$ and $\mathrm{La} / \mathrm{Yb}$ ratio of 31 , which is in the middle range of 114 mafic and intermediate alkaline rocks from the Velay province. However, $\mathrm{Zr}$ content is only 115 around $420 \mathrm{ppm}$, falling in the low range of the Velay volcanic rocks.

\section{Analytical techniques}

122 CAMEBAX SX100 electron microprobe at the laboratoire Domaines Océaniques (University of Brest) using a $15 \mathrm{kV}$ and $10 \mathrm{nA}$ beam focused to a spot of $\sim 2 \mu \mathrm{m}$ in diameter. The peaks 
loss by volatilization. Oxides, natural mineral and synthetic standards have been used. Matrix corrections were performed by the PAP-procedure in the CAMECA software.

In situ $U-P b$ dating

Zircons were separated at the Laboratoire Magmas et Volcans (LMV), ClermontFerrand (France) using standard techniques of crushing and sieving, followed by Wilfley table, magnetic separation and heavy liquids before handpicking under binocular microscope. They were mounted in epoxy disks and polished to expose crystal interiors. Cathodoluminescence (CL) imaging was conducted at LMV using a JEOL JSM-5910LV SEM. U-Th-Pb isotope data were measured by laser ablation inductively coupled mass spectrometry (LA-ICP-MS) at LMV. Zircons were ablated under pure He using a Resonetics Resolution M-50 system equipped with a $193 \mathrm{~nm}$ Excimer laser coupled to a Thermo Element XR sector field ICP-MS. $\mathrm{N}_{2}$ was supplemented to $\mathrm{Ar}$ and $\mathrm{He}$ carrier gas for sensitivity enhancement (Paquette et al., 2014). The laser operated with a spot diameter ranging from 47 to $60 \mu \mathrm{m}$, a repetition rate of $3 \mathrm{~Hz}$, and a fluence of $2.5 \mathrm{~J} / \mathrm{cm}^{2}$. Complete instrumental operating conditions and data acquisition parameters are described in Table S1.

The Element was tuned to maximize the ${ }^{238} \mathrm{U}$ intensity and minimize $\mathrm{ThO}^{+} / \mathrm{Th}^{+}(<1 \%)$ using the NIST SRM 612 glass. After 10 pre-ablating cleaning pulses, background levels were measured on-peak with the laser off for $\sim 30 \mathrm{~s}$, followed by $\sim 60 \mathrm{~s}$ of measurement with the laser firing and then $\sim 10 \mathrm{~s}$ of washout time (see for detail Mullen et al., 2018 and Paquette et al., 2019a). Reduction of raw data was carried out using the GLITTER® software package (van Achterbergh et al., 2001). Isotope ratios were corrected for laser-induced and instrumental mass fractionation via sample-standard bracketing using the GJ-1 zircon reference material (Jackson et al., 2004). The ${ }^{235} \mathrm{U}$ signal is calculated from ${ }^{238} \mathrm{U}$ based on the 
ratio ${ }^{238} \mathrm{U} /{ }^{235} \mathrm{U}=137.818$ (Hiess et al., 2012). The 91500 zircon reference material

151 (Wiedenbeck et al., 1995) was analyzed along with the samples to independently monitor the external precision and accuracy of the measurements. Common $\mathrm{Pb}$ and initial disequilibria caused by ${ }^{230} \mathrm{Th} /{ }^{238} \mathrm{U}$ and ${ }^{231} \mathrm{~Pa} /{ }^{235} \mathrm{U}$ fractionation in the zircon/melt system were corrected

154 according to Sakata et al. (2015) and Sakata (2018) method and related Microsoft Excel spreadsheet. Concentrations of $\mathrm{U}, \mathrm{Th}$, and $\mathrm{Pb}$ were calculated by normalization to the certified composition of GJ-1 reference material (Jackson et al., 2004). A Th/ $\mathrm{U}_{\text {melt }}$ ratio for the whole rock of 4.1 is considered (see Table 1). The available fractionation factor of $\mathrm{Pa} / \mathrm{U}$ in a zirconmelt system of rhyolitic composition roughly shows agreement with a value of $2.9 \pm 1.0$ (Sakata, 2018), which was propagated into the calculations. The isotopic ratios and ages together with all of the uncertainties were corrected from elemental and isotopic fractionation,

161 common $\mathrm{Pb}$ contribution and $\mathrm{Th} / \mathrm{U}$ disequilibria correction. Weighted mean ${ }^{206} \mathrm{~Pb} /{ }^{238} \mathrm{U}$ ages and ${ }^{207} \mathrm{~Pb} /{ }^{206} \mathrm{~Pb}$ versus ${ }^{238} \mathrm{U} /{ }^{206} \mathrm{~Pb}$ diagrams (Tera and Wasserburg, 1972) were generated using Isoplot/Ex v. 2.49 software package by Ludwig (2001). Error ellipses for each point are quoted at the $2 \sigma$ level and integrate both internal and external uncertainties by quadratic addition.

In situ Hf isotopes Plus multi-collector ICP-MS coupled to the Resonetics M50E $193 \mathrm{~nm}$ laser excimer system 171 (LMV). The MC-ICP-MS is equipped with 9 Faraday cups and amplifiers with $10^{11} \Omega$. Data 172 were collected in static mode $\left({ }^{171} \mathrm{Yb},{ }^{173} \mathrm{Yb},{ }^{174} \mathrm{Hf},{ }^{175} \mathrm{Lu},{ }^{176} \mathrm{Hf}-{ }^{176} \mathrm{Yb}-{ }^{176} \mathrm{Lu},{ }^{177} \mathrm{Hf},{ }^{178} \mathrm{Hf}\right.$,

$\left.173{ }^{179} \mathrm{Hf}\right)$. The overall operating conditions and instrument settings are reported in Table S1 and 174 described in Moyen et al. (2017) and Paquette et al. (2017). Each LA-MC-ICPMS analysis 
consisted of $20 \mathrm{~s}$ of gas background data followed by $40 \mathrm{~s}$ of ablation. With an integration time of $1 \mathrm{~s}$, each analysis typically produced 36-40 isotopic ratios. Mass bias effects on $\mathrm{Hf}$ were corrected using an exponential law and a true value for ${ }^{179} \mathrm{Hf} /{ }^{177} \mathrm{Hf}$ of 0.7325 (Patchett and Tatsumoto, 1980; Patchett et al., 1981). Data were reduced in the following order and based upon user-selected background and sample integration intervals. Firstly, the mean signal intensity of the background was subtracted from the signal acquired during the laser firing onto the sample. $\beta_{\mathrm{Yb}}$ was determined using the ${ }^{173} \mathrm{Yb} /{ }^{171} \mathrm{Yb}$ measured during each analysis and the reference value for ${ }^{173} \mathrm{Yb} /{ }^{171} \mathrm{Yb}$ of 1.132685 (Chu et al., 2002; Fisher et al., 2011a). The ${ }^{176} \mathrm{Yb}$ and ${ }^{176} \mathrm{Lu}$ isobaric interference on ${ }^{176} \mathrm{Hf}$ were determined using ${ }^{176} \mathrm{Yb} /{ }^{173} \mathrm{Yb}$ of 0.79618 and the measured interference-free ${ }^{175} \mathrm{Lu}$ mass assuming that $\beta_{\mathrm{Lu}}=\beta_{\mathrm{Yb}}$, and using the reference value for ${ }^{176} \mathrm{Lu} /{ }^{175} \mathrm{Lu}$ of 0.02655 (Vervoort et al., 2004).

Both determined ${ }^{176} \mathrm{Lu}$ and ${ }^{176} \mathrm{Yb}$ signals were subtracted from the total 176 signal intensity. The mass bias is calculated using the true ${ }^{179} \mathrm{Hf} /{ }^{177} \mathrm{Hf}$ ratio of 0.7325 (Patchett and Tatsumoto, 1980). Finally the interference corrected ${ }^{176} \mathrm{Hf} /{ }^{177} \mathrm{Hf}$ is evaluated according to the following equation:

$$
\left(\frac{176 H f}{177 H f}\right)_{\text {corrected }}=\left(\frac{{ }^{176}(H f+Y b+L u)_{\text {meas }}-{ }^{176} \mathrm{Yb}_{\text {calc }}-{ }^{176} L u_{\text {calc }}}{{ }^{177} H f_{\text {meas }}}\right) \times\left(\frac{M 176}{M 177}\right)^{\beta(H f)}
$$

The ${ }^{176} \mathrm{Lu} /{ }^{177} \mathrm{Hf}$ for all samples were corrected for mass bias using $\beta$ Hf. Outlier rejection of the Hf isotopic ratio for each analysis were performed using a two-standard deviation criterion.

The $\varepsilon_{\mathrm{Hf}}(\mathrm{t})$ value is defined as the deviation of the ${ }^{176} \mathrm{Hf} /{ }^{177} \mathrm{Hf}$ of a sample from the CHUR in parts per $10^{4}$. It is calculated according to the $\lambda^{176} \mathrm{Lu}$ value $=1.865 \times 10^{-11} \mathrm{yr}^{-1}$ of Scherer et al. $(2001)$ and the CHUR parameters $\left({ }^{176} \mathrm{Hf} /{ }^{177} \mathrm{Hf}=0.282793 ;{ }^{176} \mathrm{Lu} /{ }^{177} \mathrm{Hf}=0.0338\right)$ of Iizuka et al. (2015).

In order to certify the Hf isotope results, we checked our analytical reproducibility and correction procedure with systematic measurement of 20 replicates of four synthetic zircons 
displaying increasing $(\mathrm{Y}+\mathrm{Lu})$ content (Supplementary Table S2). Mean and two standard 201 deviation values obtained on MUNZirc $0-2 \mathrm{a}\left({ }^{176} \mathrm{Hf} /{ }^{177} \mathrm{Hf}=0.28213 \pm 3\right)$, MUNZirc $1-2 \mathrm{~b}$ $(0.28214 \pm 2)$; MUNZirc 3-2b (0.28215 \pm 2$)$ and MUNZirc 4-2b $(0.28216 \pm 3)$ are fully consistent with reference values (Fischer et al., 2011b).

\section{Analytical results}

\section{Mineral chemistry and origin}

Minerals have been analysed in three different occurrences: 1) in granulite xenoliths contained in the studied volcanic rock; 2) in the groundmass of the same volcanic rock; 3) in

211 alluvium associated with the studied zircons. The analysed mugearite contains xenoliths of mantle (lherzolites) and lower crustal rocks (granulites). The chemical composition of the minerals analysed in the groundmass or in alluvium has been compared to the composition of minerals from the xenoliths (granulites) contained in the rock, or from granulites and peridotites found as xenoliths in other volcanic localities from the Massif Central.

The composition of clinopyroxene $(\mathrm{Cpx})$ is highly variable and plot within three 217 different groups (Fig. 2a and Supplementary Table S3). One group has low $\mathrm{TiO}_{2}$ and high $218 \mathrm{FeO}_{\mathrm{t}}$. These compositions are similar to $\mathrm{Cpx}$ analysed in granulite xenoliths included in the 219 volcanic rock, and are identical to those encountered in granulite xenoliths from the French 220 Velay volcanic Province (Leyreloup, 1973). Cpx from granulites are found in thin section and 221 in alluvium, while mantle Cpx are found only in alluvium. The second group has also low $222 \mathrm{TiO}_{2}$ content but low $\mathrm{FeO}_{\mathrm{t}}$. These compositions are similar to diopside analysed in mantle 223 peridotite xenoliths from the French Massif Central (Chazot, unpublished data) and confirm 224 the presence of disaggregated mantle xenoliths in the mugearite. The third group of Cpx has 
high $\mathrm{TiO}_{2}$ and intermediate $\mathrm{FeO}_{\mathrm{t}}$ contents. They are found both in the groundmass and in 226 alluvium and represent Cpx crystallized from the melt. They are high-Ca diopside, with chemical compositions typical of Cpx from alkaline magmatic series (Leterrier et al., 1982).

They define two different groups (Fig.2b and Supplementary Table S2). One group with crystals from alluvium, has high silica content and low $\mathrm{FeO}_{\mathrm{t}}$, and is similar to Opx from mantle xenoliths (Chazot, unpublished data). The second group contains minerals from the granulite xenoliths in the studied rock as well as crystals from the alluvium. Their composition, with low silica but higher $\mathrm{FeO}_{\mathrm{t}}$ content, is similar to Opx analysed in granulite xenoliths from the French Massif Central (Leyreloup, 1973). Accordingly, no Opx composition corresponds to minerals crystallized from the melt. wt.\%) and are typical mantle olivine, similar to those analysed in mantle xenoliths, while other grains have higher $\mathrm{FeO}_{\mathrm{t}}$ and lower silica content and have crystallized from the melt. well as from free grains in the groundmass. They all have chemical compositions in the range 241 of garnets analysed in granulite xenoliths from the French Massif Central (Leyreloup, 1973); consequently, they all come from the lower crustal granulites.

Analyses of feldspar have been obtained from alluvium, from the groundmass and

244 from granulite xenoliths in the mugearite. In the groundmass, they are plagioclase ranging 245 from andesine to labradorite. In granulites and alluvium, the compositions are very variable 246 and range from plagioclase to sodic sanidine.

All these results show that the zircon-bearing mugearite contains minerals which crystallized from the melt, or which have been sampled all along the way from the mantle to the surface, and derived either from the upper mantle itself or from the continental crust. 
250 Granulite xenoliths, as well as numerous minerals with granulitic composition, indicate a

251 strong interaction between the uprising melt and the lower crust.

\section{Zircon morphology}

All the crystals sampled for this study are large $(>200 \mu \mathrm{m})$ and red-coloured. Isolated crystals from alluvium deposits are the largest, up to several millimetres long. These are always euhedral to subhedral with frequent slightly rounded pyramids and sometimes corroded faces (Fig. 3A). In cathodoluminescence, these large crystals display an igneoustype fine sector oscillatory zoning which is strictly parallel to the crystal faces (Fig. 3B). 260 Zircon rims, although locally rounded by corrosion or abrasion, display sharp outlines without alteration features.

Two different morphologies occur among the zircon crystals separated from the mugearite samples. A scarce population is composed of euhedral to subhedral zircon grains, sometimes broken and displaying a broadly similar morphology to the previous ones (Fig. 3C). They are also characterized by sector zoning but their sides are often paler than their centres in the cathodoluminescence images. These crystals can be outlined by a fine alteration rim (Fig. 3D). The main population of zircons from the mugearite is composed of spherical to ovoid crystals. In cathodoluminescence, these round grains are characterised by a sector (Fig. 3E and F) or an oscillatory zoning (Fig. 3G), which remains clearly visible. This zoning is always incomplete and crosscut the crystal limits (Fig. 3E, F and G). This spherical shape 271 probably results from the chemical disequilibrium between the zircon and the mafic melt, causing dissolution of previously euhedral or subhedral zoned zircon crystals. Similarly to the

273 euhedral population, a thin and light-coloured rim (Fig. 3G), maybe related to a fluid 274 interaction stage, surrounds the whole grains. In some of these rounded grains, the presence 
of cores, located close to the centre of the crystals, is suspected (Fig. $3 \mathrm{H}$ ). Visible inclusions were not detected; this is consistent with the moderate $\mathrm{U}$ and Th contents of the zircons megacrysts and their use as gemstones in jewellery.

$$
\text { U-Pb geochronology }
$$

The dataset for ESP-2 zircon megacrysts from Les Brus stream comprises 55 laser spots performed on thirteen crystals. 52 pooled measurements on twelve of the thirteen analysed zircons yield a weighted mean ${ }^{206} \mathrm{~Pb} /{ }^{238} \mathrm{U}$ concordant age of $2.629 \pm 0.024 \mathrm{Ma}$ (Fig. $4 \mathrm{~A}$ and Table 2) after correcting for the common $\mathrm{Pb}$ and $\mathrm{Th} / \mathrm{U}$ disequilibria. The three remaining analyses on the last zircon grain yield a significantly older age of $10.06 \pm 0.39 \mathrm{Ma}$. Both ages, $10.06 \mathrm{Ma}$ and $2.63 \mathrm{Ma}$, are interpreted as reflecting the crystallization ages of two distinct episodes of zircon formation, the younger one being better sampled. The U content of the main population ranges from 39 to $664 \mathrm{ppm}$ but is variable from grain to grain and particularly from zone to zone inside each grain up to a factor of five. Th/U ratios of $1.2 \pm 0.5$ (1 standard deviation) are systematically high and typical of magmatic zircons from alkaline volcanic environments (Paquette and Mergoil-Daniel, 2009; Hurai et al., 2012 and 2013, Huraiova et al., 2017; Paquette et al., 2019b).

A second set of 78 spots was performed in 49 zircon grains separated from the ESP-1 mugearite. These zircon crystals are mostly fully rounded, about ten are broken with sharp angles between faces, consequently their original shape cannot be distinguished, and two are subhedral. Among these different morphologies, the U-Pb dating results can be easily divided into two groups. The first one comprised rounded, broken and euhedral zircon grains yielding together a weighted mean ${ }^{206} \mathrm{~Pb} /{ }^{238} \mathrm{U}$ concordant age of $2.579 \pm 0.033 \mathrm{Ma}$ (Fig. 4B and Table 2) corrected for the common $\mathrm{Pb}$ and $\mathrm{Th} / \mathrm{U}$ disequilibria. Similarly to ESP-2 zircon 
megacrysts, $\mathrm{U}$ and Th content are highly variable, ranging from 75 to $1340 \mathrm{ppm}$ and from 50 to $2706 \mathrm{ppm}$, respectively. U content may increase by a factor of four between dark and light cathodoluminescence zones inside each grain. These Pliocene zircons provide systematically high $\mathrm{Th} / \mathrm{U}$ ratios of $1.4 \pm 0.6$ ( 1 standard deviation), which agree with a similar magmatic environment as the ESP-2 zircon megacrysts sampled in the neighbouring stream. The subhedral morphology of some synchronous grains possibly represents crystals that have been better preserved from dissolution. The second dated group is also composed of rounded zircons but yield an older lower intercept age of $284.7 \pm 3.1 \mathrm{Ma}$ (Fig. 4C and Table 2). Lower $\mathrm{U}$ content and $\mathrm{Th} / \mathrm{U}$ ratios than those of the Pliocene zircons, range from 53 to $538 \mathrm{ppm}$ and from 0.04 to 1.0 , respectively, with a mean value for the latter of $0.5 \pm 0.3$. We never observed any Permian core-Pliocene rim combination, each zircon type being consistent in age.

\section{Lu-Hf isotopes}

All the Lu-Hf analyses of ESP-2 zircon megacrysts yield super-chondritic initial $\varepsilon_{(\mathrm{Hf})}$ values (Supplementary Table S4 and Fig. 5) ranging from +7.0 to +12.9 with a mode of +9.2 \pm 1.4 (1 standard deviation). $\varepsilon_{(\mathrm{Hf})}$ values may evolve significantly above uncertainties between different spots in several individual grains. Similar variability within single grains and between different zircon megacrysts occurring in comparable geological context has already been reported (e.g. Huraiová et al., 2017; Paquette et al., 2019b). This has been correlated with heterogeneous and metasomatized mantle, affected only marginally by recycled continental crust. Depleted Mantle Hf model ages $\mathrm{T}_{\mathrm{DM}}(\mathrm{Hf})$ are very consistent around a mean value of $348 \pm 56 \mathrm{Ma}$ (1 standard deviation). The Miocene \#A01 zircon grain provides an initial Hf isotope composition which is at the lower limit of those of the Pliocene crystals. 
In the ESP-1 mugearite sample, both zircon types identified by $\mathrm{U}-\mathrm{Pb}$ dating are still

valid. The Pliocene zircon population from the lava displays super-chondritic initial $\varepsilon_{(\mathrm{Hf})}$ values (Supplementary Table S4 and Fig. 5) ranging from +7.2 to +14.8 with a mode of +10.1 \pm 1.8 (1 standard deviation). This variability is interpreted similarly than for ESP-2 zircon megacrysts and demonstrates a significant heterogeneity of the mantle source, possibly weakly affected by contribution of continental crust. $\mathrm{T}_{\mathrm{DM}}(\mathrm{Hf})$ model ages are also consistent around a mean age of $307 \pm 68 \mathrm{Ma}$. Consequently, all the Neogene zircon grains, both those from the stream sediment and those extracted from the mugearite, provide similar superchondritic initial $\varepsilon_{(\mathrm{Hf})}$ values. This implies that the parental magmas of the source rocks for these zircon grains were juvenile and formed from a depleted mantle source characterized in both cases by Carboniferous $\mathrm{T}_{\mathrm{DM}}(\mathrm{Hf})$ model ages. The second age group comprising the Permian zircons yield significantly different Hf initial isotope compositions with slightly super-chondritic to mostly sub-chondritic initial $\boldsymbol{\varepsilon}_{(\mathrm{Hf})}$ values ranging from +0.7 to -14.1 . These negative initial $\varepsilon_{(\mathrm{Hf})}$ values document that the zircon parental rocks were derived from sources dominated by recycled crustal material. In other words, the Neogene zircon group is mantlederived whereas the Permian one is continental crust-derived.

\section{Discussion: origin and formation of the zircons}

$$
\text { On the basis of petrological observations, in-situ geochemistry on minerals, U-Pb }
$$
geochronology, and $\mathrm{Hf}$ isotopic data, the origin and formation of the zircon crystals can be outlined as follows.

First, Hf isotopes demonstrate that all Neogene zircons crystallized from a melt derived from a depleted mantle source. However, this depleted mantle source is different from 
348 the depleted mantle sources for mid-ocean ridge basalts which are characterized by initial $\varepsilon_{(\mathrm{Hf})}$

349 values around +18 . Rather, the intermediate initial $\varepsilon_{(\mathrm{Hf})}$ values ranging from +7.0 to +14.8

350 suggest a metasomatized sub-continental lithospheric mantle. Subsequent enrichment of the 351 mantle in incompatible trace elements such as HFSE, Th and U (Aulbach et al., 2008; 352 Kalfoun et al., 2002; Pfänder et al., 2012) by carbonatite metasomatism can be considered 353 beneath the French Massif Central (Chazot et al., 2003; Paquette and Mergoil-Daniel, 2009; 354 Chazot and Mergoil-Daniel, 2012). This is probably responsible for some variability of the 355 $\varepsilon_{(\mathrm{Hf})}$ values, as well as the possibility of a weak continental crust assimilation. Such a metasomatized lithospheric mantle source is favoured beneath the Velay area. According to Carboniferous $\mathrm{T}_{\mathrm{DM}}(\mathrm{Hf})$ model ages, this lithospheric mantle may have been fertilized during the Cenozoic from an asthenospheric mantle fragment formed during Variscan times. Important modifications in the mantle beneath the French Massif Central during 360 Variscan times have already been demonstrated from mantle studies. Hf isotopes in 361 clinopyroxene from mantle xenoliths lie along a $360 \mathrm{Ma}$ "isochron" (Wittig et al., 2006; 362 2007), indicating extensive partial melting of a mantle wedge becoming the new lithospheric 363 mantle in this area. $\mathrm{Nd}$ isotopes are consistent with these observations. Available data on 364 mantle clinopyroxene from various volcanic centres in the Massif Central (Downes and 365 Dupuy, 1987; Downes et al., 2003; Touron et al., 2008; Xu et al., 1998; Yoshikawa et al., 366 2008; Zangana et al., 1997) plot on a similar "isochron" from which the slope defines an age 367 of $345 \mathrm{Ma}$ (Fig. 6). The initial ${ }^{143} \mathrm{Nd} /{ }^{144} \mathrm{Nd}$ value of the isochron is 0.51267 , very close to the $368 \mathrm{Nd}$ isotopic value of the depleted mantle recalculated at the same age $\left({ }^{143} \mathrm{Nd} /{ }^{144} \mathrm{Nd} \mathrm{d}_{\mathrm{i}}=0.51263\right.$, 369 Gale et al., 2013). This confirms the conclusions obtained by Wittig et al. (2006 and 2007) 370 that the depleted mantle beneath the French Massif Central underwent partial melting during 371 or at the end of the Hercynian orogeny. This part of the mantle was then incorporated into the 372 lithosphere and subsequently metasomatized and melted during Cenozoic and Quaternary 
volcanism. The chemical evolution of asthenospheric mantle towards lithospheric mantle may occur during or at the end of Hercynian continental collision. Detachment and sinking of the lithospheric mantle with or without a portion of the lower crust results in asthenosphere upwelling and cooling to replace the missing mantle root (Kay and Kay, 1993; GutiérrezAlonso et al., 2011). Partial melting during upwelling of the asthenospheric mantle is often advocated to explain heat and magma transfer to the crust during and at the end of an orogeny (e.g. Schott and Schmeling, 1998; Lustrino, 2005; Li et al., 2016). This model is in good agreement with the Hercynian model ages calculated with Hf isotopes in our zircons, and provides more evidence that these zircons crystallized from melts formed in the lithospheric mantle.

\section{The origin of zircon megacrysts in mafic or intermediate volcanic rocks has been} debated for a long time. Old zircons can be sampled throughout the crust during magma ascent. In that case, they are older than the volcanic host-rock and genetically unrelated to the volcanic event. The Permian zircon population sampled in the ESP-1 mugearite and dated at $285 \mathrm{Ma}$, can be related to the late metamorphic evolution of the Variscan belt, when felsic granulites crystallized in the lower continental crust (e.g. Pin and Vielzeuf, 1983; Paquette et al., 2003). Enclaves from Variscan granulitic metasediments scavenged by basaltic volcanism in the northern Massif Central were already sampled and studied (Rossi et al., 2006).

Several studies have demonstrated that volatile fluxes interacting with the lithospheric mantle in an environment enriched in incompatible elements promote the generation of felsic melts by low degree partial melting (Aspen et al., 1990; Hinton and Upton, 1991). Large zircon grains can crystallize from these melts within small dykes in the mantle (Upton et al., 1999; Pin et al., 2001 and 2006; Sutherland et al., 2002). Despite such lithologies have rarely been identified in mantle xenoliths worldwide (Shimizu et al., 2004; Avanzinelli et al, 2020), 
minerals from these rocks could be scavenged by ascending magmas and carried up to the

399 surface. In those situations, one can expect associated minerals to be transported along with

400 the zircons. Furthermore, the age of the zircons must be older than the age of the eruption and

401 in some cases, the zircons should be genetically unrelated to the host magmas. Our studied

402 samples contain many xenocrysts (garnet, orthopyroxene, clinopyroxene), but none of these

403 minerals can be associated with felsic rocks formed in the mantle and we have no indication

404 that the studied zircons were formed at mantle depth. Xenocrysts contained in our samples

405 have a crustal origin, as is probably the case for the associated zircons.

406 Paquette and Mergoil-Daniel (2009) reported the occurrence of zircon-bearing

407 nepheline syenite xenoliths formed from differentiated mantle-derived magmas in

408 neighbouring areas from the French Massif Central. These felsic magmas can be derived

409 through fractional crystallization in crustal magma chamber from ascending alkaline mafic

410 magmas formed in the lithospheric mantle. Such alkaline felsic melts may generate the large

411 volumes of zircon megacrysts discovered worldwide in secondary deposits within continental

412 basaltic provinces (e.g. Garnier et al., 2004 and 2005). Scavenging of the crystallizing melt

413 during recharge of the magma chamber by a new batch of more mafic magma can explain the

414 presence of these zircon megacrysts in our studied samples. The discovery of sodic sanidine

415 crystals associated with the zircons in the alluvium samples is in good agreement with the

416 presence of crystallizing syenitic bodies in the crust, through which the mafic magma passed,

417 en route to the surface. This kind of shallow magma chamber with a zircon-rich syenitic

418 magma has already been described in Quaternary Eifel volcanoes of Germany where zircon

419 are mostly contained in lapilli-sized plutonic ejecta (Schmitt et al., 2017).

421 With more than $51 \% \mathrm{SiO}_{2}$ and less than $60 \mathrm{ppm} \mathrm{Ni}$, the host magma is far from a 422 primitive melt in equilibrium with mantle lithology. This indicates that this magma has 
already undergone crystal fractionation at greater depth in the crust. It is probably during this

424 earlier differentiation episode that mantle xenoliths were partly disaggregated and mantle minerals such as olivine, Opx and Cpx incorporated into the magma. The presence of granulite xenoliths, and xenocrysts from granulite lithologies, may indicate that differentiation occurred at great depth in the lower crust. Magma transfer towards the surface would then follow a similar pathway previously used and bring the magma into a shallow syenitic magma chamber where zircon and sanidine were incorporated into the ascending magma before eruption.

Zircons from both stream sediments and lavas originated from a common source by

433 similar petrogenetic processes and crystallized synchronously within uncertainties during a 434 single event in the mid-upper Pliocene (Piacenzian-Gelasian boundary). A comparable U-Pb 435 age of about 2.51 Ma (uncorrected from Th-Pa disequilibria; Wiedenbeck et al., 1995; 436 Cocherie et al., 2009) was obtained on a quite similar zircon megacryst from the National 437 Muséum d'Histoire Naturelle in Paris and recorded as belonging to a deposit at Croustet 438 (Haute Loire, France), probably close to our sampling area. Furthermore, all the zircon 439 crystals in the sedimentary deposit are large and euhedral without any partial dissolution 440 illustrating a lack of - or very limited - dissolution time and disequilibrium between the 441 mineral and the magma. In contrast, most zircons from the lava are rounded which edges that 442 crosscut the zoning of the crystals. A very thin luminescent rim at the border of the grains 443 coupled with irregular small dissolved gulfs can be linked to a late fluid activity during the 444 cooling of the lava flow. All these features are related to the incomplete equilibration between 445 zircon xenocrysts, or zircon-bearing xenoliths, and the mafic melt. Consequently, the major 446 difference between the zircons of both samples is essentially related to their extraction from 447 the felsic magmas and uplift to the surface, which preserves the euhedral megacrysts and not 
the rounded zircons. These latter are obviously connected to mafic lava flows scavenging, and partly dissolving, both mantle and lower-crustal enclaves. The rare subhedral zircon crystals discovered in the mugearite sample were probably shielded in larger felsic xenoliths from the corrosion of the mafic magma.

The preserved morphology of zircon megacrysts from sedimentary deposits implies a different sampling and uplift mechanism, without any dissolution by interaction with a mafic magma. Basically, the scavenging of enclaves and their uplift may also be performed by more felsic lavas. Trachyte domes preserving deep xenoliths and xenocrysts are known in the French Massif Central (e.g. Brousse and Varet, 1966). A major drawback of this hypothesis is that zircon megacrysts are sampled in secondary deposits, which would imply that the trachytes would be entirely dismembered by erosion. Indeed, the Devès volcanic domain is essentially basaltic in composition, without significant occurrence of felsic lavas. Furthermore, there is no evidence and geologic reason for global differential erosion of the felsic lavas and preservation of synchronous mafic ones. Consequently, this hypothesis seems rather unlikely. Another opportunity to restrict the time of interaction between lavas, xenoliths and xenocrysts is the occurrence of phreatomagmatic eruptions. Such events do not preserve 464 significant volcanic structures 2.6 Myrs after eruption (e.g. Paquette et al., 2019b), whereas sediments related to ancient maar craters often contain large amounts of euhedral zircon megacrysts (e.g. Hurai et al., 2010; 2012 and 2013; Huraiova et al., 2017). In our present

467 knowledge, we consider that hypothesis as the most likely. We propose a two-steps process in 468 which a magma containing mantle and lower crust xenoliths was scavenging a zircon-bearing 469 felsic assemblage in a crystallizing shallow magma chamber during its ascent. The first part of 470 the eruption was characterized by phreatomagmatic activity and a very brief interaction 471 between the magma and the zircon megacrysts. These zircons can thus preserve their euhedral 472 shape. The second part of the eruption was less violent, with emplacement of a lava flow and 
473 longer interaction between the magma and the zircon megacrysts. Those zircons acquire their 474 rounded shape during this effusive part of the eruption.

\section{Conclusion}

477

In the south eastern Devès volcanic domain of the French Massif Central, we report the rare occurrence of zircon megacrysts in, both, alluvium of a small stream and within a neighbouring alkaline lava. The crystals from the alluvial deposit display a subhedral morphology while the zircons in the lavas are completely rounded.

Both zircon types share common $\mathrm{U}-\mathrm{Pb}$ ages of about 2.6 Ma, synchronous within uncertainties, and mantle-derived super chondritic Hf isotopic signatures.

The analysed mugearite also contains xenoliths of mantle and lower crustal rocks (granulites). The chemical composition of the minerals analysed in the groundmass is similar to the composition of those from the xenoliths (granulites), or from granulites and peridotites found as xenoliths in other volcanic localities from the Massif Central. The mugearite lava also preserves rounded Variscan zircon crystals dated at $285 \mathrm{Ma}$ and originating from lower continental crust.

In spite of their mantle origin recorded by in situ Hf isotopes, the Pliocene zircons cannot have crystallized directly in the mantle or in mantle-derived mafic melts. We propose that these zircons crystallized from felsic melts produced during extensive differentiation of mantle-derived magmas within the continental crust. Finally, a last more mafic magma batch en route to the surface scavenged upper mantle and lower crust xenoliths as well as zircon xenocrysts from the felsic melts during its ascent.

Many continental volcanic basaltic fields are associated to alluvial deposits containing Cenozoic zircon megacrysts as well as sapphire gemstones. Such occurrences are reported in 
498 the western and central European volcanic province which includes the French Massif

499 Central. This would imply that significant volumes of felsic differentiate issued from mantle500 derived basaltic magmas, and consequently huge amounts of zircon megacrysts, may have 501 been produced in the alkaline volcanic domains at the global scale.

502

503

504

505

506

\section{$\underline{\text { Acknowledgements }}$}

The authors are grateful to M. Brun from the "Ferme des Brus" who kindly shared his zircon concentrate sampled in the Ruisseau des Brus and to Shuhei Sakata from Gakushuin University Tokyo for providing advice and spreadsheet for $\mathrm{Th} / \mathrm{U}$ disequilibria calculation. We warmly thanked the professors Hilary Downes and Massimo Tiepolo for their helpful reviews, and the editor Dr. Kelly Russell for his great efficiency.

This research was supported by the French Government Laboratory of Excellence initiative $\mathrm{n}^{\circ}$ ANR-10-LABX-0006. This is Laboratory of Excellence ClerVolc contribution number 403 .

\section{References}


mantle revealed by trace element and $\mathrm{Sr}-\mathrm{Nd}-\mathrm{Pb}$ isotopic data in composite xenoliths from Tallante (Betic Cordillera, Spain). Lithos, 352-353, 105316.

Brousse, R., Varet, J. 1966. Les trachytes du Mont-Dore et du Cantal septentrional. Leurs enclaves. Bulletin de la Société Géologique de France, VIII, 246 -262.

Carbonnel, J.P., Robin, C., 1972. Les zircons-gemmes dans les roches ignées basiques : le gisement d'Espaly (Haute-Loire, France). Revue de Géographie Physique et de Géologie Dynamique, 14, 159-170.

Chazot, G., Mergoil-Daniel, J., 2012. Co-eruption of carbonate and silicate magmas during volcanism in the Limagne graben (French Massif Central). Lithos, 154, 130-146.

Chazot, G., Bertrand, H., Mergoil, J., Sheppard, S.M., 2003. Mingling of immiscible dolomite carbonatite and trachyte in tuffs from the Massif Central, France. Journal of Petrology, 44, 1917-1936.

Chu, N.C., Taylor, R.N., Chavagnac, V., Nesbitt, R.W., Boella, R.M., Milton, J.A., German, C.R., Bayon, G., Burton, K., 2002. Hf Isotope Ratio Analysis Using Multi-Collector Inductively Coupled Plasma Mass Spectrometry: An Evaluation of Isobaric Interference Corrections. Journal of Analytical Atomic Spectrometry, 17, 1567-1574.

Cocherie A., Fanning, M.C., Jezequel, P., Robert, M., 2009. LA-MC-ICPMS and SHRIMP U-Pb dating of complex zircons from Quaternary tephras from the French Massif Central: magma residence time and geochemical implications. Geochimica and Cosmochimica Acta, 73, 1095-1108.

Dautria, J.-M., Liotard, J.-M., Briot, D., 2004, Particularités de la contamination crustale des phonolites: exemple du Velay Oriental (Massif Central). Comptes Rendus Geoscience, 336, 971-981.

Downes, H., Dupuy, C., 1987. Textural, isotopic and REE variations in spinel peridotite xenoliths, Massif Central, France. Earth and Planetary Science Letters, 82, 121-135. 
Downes, H., Reichow, M.K., Mason, P.R.D., Beard, A.D., Thirlwall, M.F., 2003.

549 Mantle domains in the lithosphere beneath the French Massif Central: trace element and 550 isotopic evidence from mantle clinopyroxenes. Chemical Geology, 200, 71-87.

Fisher, C.M., McFarlane, C.R.M., Hanchar, J.H., Schmitz, M.D., Sylvester, P.J., Lam,

R., Longerich, H.P., 2011a. Sm-Nd isotope systematics by laser ablation-multicollectorinductively coupled plasma mass spectrometry: Methods and potential natural and synthetic reference materials. Chem. Geol., 284, 1-20.

Fisher, C.M., Hanchar, J.M., Samson, S.D., Dhuime, B., Blichert-Toft, J., Vervoort, J.,

556 Lam, R., 2011b. Synthetic zircon doped with hafnium and rare earth elements: a reference material for in situ hafnium isotope analysis. Chemical Geology, 286, 32-47.

Forestier, F.H., 1993. Histoire de l'un des gisements de gemmes le plus anciennement connu d'Europe occidentale : saphirs, grenats et hyacynthes du Puy en Velay (43) le Riou Pezzouliou, commune d'Espaly St Marcel, In : Les cahiers de la Haute Loire (Ed) France, 81148.

Gale, A., Dalton, C.A., Langmuir, C.H., Su, Y., Schilling, J.G., 2013. The mean composition of ocean ridge basalts. Geochemistry Geophysics Geosystems, 14, 489-518. corindon : classification et genèse. Le Règne Minéral, 55, 7-35.

Garnier, V., Ohnenstetter, D., Guliani, G., Fallick, A.E., Trong, T.P., Quang, V.H., Van, L.P. and Schwarz, D., 2005. Basalt petrology, zircon ages and sapphire genesis from DakNong, southern Vietnam. Mineralogical Magazine, 69, 21-38. inclusion approach to the enigma. Contribution to Mineralogy and Petrology, 122, 368-386. 
572 Gonzalo, J.C., 2011. Lithospheric delamination in the core of Pangea: Sm-Nd insight from the 573 Iberian mantle. Geology, 39, 155-158.

Hiess, J., Condon, D.J., McLean, N., and Noble, S.R. (2012) ${ }^{238} \mathrm{U} / 235$ U systematics in

591 Geochemistry, mineralogy, and zircon $\mathrm{U}-\mathrm{Pb}-\mathrm{Hf}$ isotopes in peraluminous A-type granite

592 xenoliths in Pliocene-Pleistocene basalts of northern Pannonian Basin (Slovakia).

terrestrial uranium-bearing minerals. Science, 335, 1610-1614.

Hinton, R.W., Upton, B.G.J., 1991. The chemistry of zircons: variations within and between large crystals from syenite and alkali basalt xenoliths. Geochimica et Cosmochimica Acta, 55, 3287-3302.

Hurai, V., Paquette, J.L, Huraiová, M., Konečný, P., 2010. Age of deep crustal magmatic chambers in the intra-Carpathian back-arc basin inferred from LA-ICPMS U-Th-Pb dating of zircon and monazite from igneous xenoliths in alkali basalts. Journal of Volcanology and Geothermal Research 198, 275-287.

Hurai, V., Paquette, J.L., Huraiová, M. and Sabol, M., 2012. U-Pb geochronology of zircons from fossiliferous sediments 1 of the Hajnáčka I maar (Slovakia) - type locality of the MN16a biostratigraphic subzone. Geological Magazine, 149, 989-1000.

Hurai, V., Danišík, M., Huraiová, M., Paquette, J.L., Konečný, P., Konečný, V.,Ádám, A., 2013. Combined U-Pb and (U-Th)/He geochronometry of basalt maars - implications for age of intraplate volcanism and origin of zircon metasomatism in Western Carpathians. Contribution to Mineralogy and Petrology, 166, 1232-1251.

Huraiová, M., Paquette, J.L., Konečný, P., Gannoun, A., Hurai, V., 2017. Contribution to Mineralogy and Petrology, 172, 59. 
Iizuka, T., Yamaguchi, T., Hibiya, Y., Amelin, Y., 2015. Meteorite zircon constraints

595 on the bulk $\mathrm{Lu}-\mathrm{Hf}$ isotope composition and early differentiation of the Earth. Proceedings of 596 the National Academy of Sciences, 112, 5331-5336.

Jackson, S.E., Pearson, N.J., Griffin, W.L., and Belousova, E.A., 2004. The

598

599

600

601

602

603

604

605

606

607

608

609

610

611

612

613

614

615

616

617

application of laser ablation-inductively coupled plasma-mass spectrometry to in situ U-Pb zircon geochronology. Chemical Geology, 211, 47-69.

Kalfoun, F., Ionov, D., Merlet, C., 2002. HFSE residence and $\mathrm{Nb} / \mathrm{Ta}$ ratios in metasomatised rutile-bearing mantle peridotites. Earth and Planetary Science Letters, 182, 117.

Kay, R.W., Kay, S.M., 1993, Delamination and delamination magmatism, Tectonophysics, 219, 177-189.

Lacroix, A., 1901. Minéralogie de la France et de ses colonies. Ch Béranger Ed. Tome troisième, $816 \mathrm{pp}$.

Leterrier, J., Maury, R., Thonon, P., Girad, D., Marchal, M., 1982. Clinopyroxene composition as a method of identification of the magmatic affinities of paleoseries. Earth and Planetary Science Letters 59, 139-154.

Leyreloup, A., 1973. Le socle profond en Velay d'après les enclaves remontées par les volcans néogènes - son métamorphisme et sa lithologie : granites et série charnockitique (Massif Central Français), PhD Thesis, University of Nantes, 356 p. orogens: A systematic numerical study. Journal of Geophysical Research, 121, 5186-5211.

Ludwig, K.R., 2001.User's manual for Isoplot/Ex Version 2.49, a geochronological toolkit for Microsoft Excel. Berkeley Geochronological Center, Special Publication 1a, Berkeley, USA, 55 pp. 
619 influence basaltic magmatism. Earth-EcienceReview, 72, 21-38.

Moine, B., 2017. Paleoproterozoic rejuvenation and replacement of Archaean lithosphere:

evidence from zircon $\mathrm{U}-\mathrm{Pb}$ dating and $\mathrm{Hf}$ isotopes in crustal xenoliths at Udachnaya, Siberian craton. Earth and Planetary Science Letters, 457, 149-159. evolution of the Northern Cascade Arc magmatism revealed by LA-ICP-MS U-Pb zircon dating. Canadian Journal of Earth Sciences, 55, 443-462.

Paquette, J.L., Mergoil-Daniel, J., 2009. Origin and U-Pb dating of zircon-bearing nepheline syenite xenoliths preserved in basaltic tephra (Massif Central, France). Contribution to Mineralogy and Petrology, 158, 245-262. granitic pulses in a post-collisional setting: evidence from precise U-Pb zircon dating through a crustal cross-section in Corsica. Chemical Geology, 198, 1-20. provenance and Precambrian evolution of the Anabar Shield from U-Pb and $\mathrm{Lu}-\mathrm{Hf}$ isotope data on detrital zircons, and the history of the northern and central Siberian craton.

641 Precambrian Research, 301, 134-144. 
643 ICP-MS U/Pb zircon timescale constraints of the Pleistocene latest magmatic activity in the

644 Sancy stratovolcano (French Massif Central). Journal of Volcanology and Geothermal 645 Research, 374, 52-61.

647 Origin and provenance of $2 \mathrm{Ma}-2 \mathrm{Ga}$ zircons ejected by phreatomagmatic eruptions of 648 Pliocene basalts in southern Slovakia. International Journal of Earth Sciences, 108, 2607649 2623.

Patchett, P.J., Tatsumoto, M., 1980. Hafnium isotope variations in oceanic basalts. Geophysical Research Letters, 7, 1077-1080.

Patchett, P.J., Kouvo, O., Hedge, C.E., Tatsumoto, M., 1981. Evolution of continental crust and mantle heterogeneity: evidence from Hf isotopes. Contribution to Mineralogy and Petrology, 78: 279-297. $\mathrm{Nb} / \mathrm{Ta}$ reservoir in the continental lithospheric mantle and consequences on the global $\mathrm{Nb}$ budget - Evidence from continental basalts from Central Germany. Geochimica et 658 Cosmochimica Acta, 77, 232-251. dualistic interpretation. Tectonophysics, 93, 47-74. of Si-Al-Na-rich low-degree partial melts from the upper mantle. Geology, 29, 451-454.

664 Igneous albitite dikes in orogenic lherzolites, western Pyrénées, France: a possible source for 
668 Fallick, A.E., Paquette, J.L., Tiepolo, M., 2014. Chemical and oxygen isotopic compositions, 669 age and origin of gem corundums in Madagascar alkali basalts. Journal of African Earth 670 Sciences, 94, 156-170. events recorded in European lower crust zircons sampled from the French Massif Central and 673 Corsica, France. Lithos, 87, 235-260. Sakata, S., 2018. A practical method for calculating the U-Pb age of Quaternary 675 zircon: Corrections for common $\mathrm{Pb}$ and initial disequilibria. Geochemical Journal, 52, 1-6. new approach for constraining the magnitude of initial disequilibrium in Quaternary zircons by coupled uranium and thorium decay series dating. Quaternary Geochronology, 37, 1-12. Scherer, E., Münker, C., Mezger, K., 2001. Calibration of the lutetium-hafnium clock. Science, 293, 683-687. Tectonophysics, 296, 225-247. Isotope and Trace Element Petrochronology of Intraplate Volcanic Rocks from the Eifel (Germany) and Implications for Mantle versus Crustal Origins of Zircon Megacrysts. Journal of Petrology, 58, 1841-1870. characteristics of felsic veins in mantle xenoliths from Tallante (SE Spain) : an insight into 689 activity of silicic melt within the mantle wedge. Transactions of the Royal society of Edinburgh: Earth Sciences, 95, 265-276. 
Simonet, C., 2000. Géologie des gisements de saphir et de rubis. L'exemple de la John

692 Saul Ruby Mine, Mangare, Kenya. PhD thesis, University of Nantes, 349 p.

694 New South Wales: Cenozoic evolution, based on basalt K-Ar ages and zircon fission track 695 and U-Pb isotope dating. Australian Journal of Earth Sciences, 48, 221-237.

Sutherland, F.L., Hoskin, P.W.O., Fanning, C.M., Coenraads, R.R., 1998. Models of corundum origin from alkali basalt terrains: a reappraisal. Contribution to Mineralogy and Petrology, 133, 356-372. 2002. Sapphire crystallization, age and origin, Ban-Huai Sai, Laos: ages based on zircon inclusions. Journal of Asian Earth Sciences, 20, 841-849. corundum and zircon megacrysts from the Mercaderes-Rio Mayo area, South-west Colombia, South America. Ore Geology Reviews, 34, 155-168. stages of original sapphire formation related to basaltic magmatism in the Bo Phloi basaltic gem field, Kanchanaburi, Western Thailand: evidence from trace elements and ages of zircons. Journal of Asian Earth Sciences, 187, 104068. the problem of initial $\mathrm{Pb}$ in lunar rocks. Earth and Planetary Science Letters, 14, 281-304.

712 Characterization of the metasomatic agent in mantle xenoliths from Devès, Massif Central 713 (France) using coupled in situ trace-element and $\mathrm{O}, \mathrm{Sr}$ and $\mathrm{Nd}$ isotopic compositions. From: 714 Coltorti, M. and Gregoire, M. (eds) Metasomatism in Oceanic and Continental Lithospheric 715 Mantle. Geological Society, London, Special Publications, 293, 177-196. 
Upton, B.G.J., Hinton, R.W., Aspen, P., Finch, A., Valley, J.W., 1999. Megacrysts and

associated xenoliths: evidence for migration of chemically enriched melts in the upper mantle beneath Scotland. Journal of Petrology, 40, 935-956.

Van Achterbergh, E., Ryan, C.G., Jackson, S.E., Griffin, W.L., 2001. Data reduction software for LA-ICP-MS. In Laser ablation-ICPMS in the earth science. P. Sylvester ed. Mineralogical Association of Canada 29, 239-243.

Vervoort, J.D., Patchett, P.J., Söderlund, U., Baker, M., 2004. Isotopic composition of $\mathrm{Yb}$ and the determination of $\mathrm{Lu}$ concentrations and $\mathrm{Lu} / \mathrm{Hf}$ ratios by isotope dilution using MC-ICPMS. Geochemistry, Geophysics, Geosystems, 5, 1-15.

Watson, E.B., 1979. Zircon saturation in felsic liquids: experimental data and applications to trace element geochemistry. Contribution to Mineralogy and Petrology, 70, 407-419.

Watson, E.B., Harrison, T.M., 1983. Zircon saturation revisited: temperature and composition effects in a variety of crustal magma types. Earth and Planetary Science Letters, 64, 295-304.

Wiedenbeck, M., Allé, P., Corfu, F., Griffin, W. 1., Meier, M., Oberli, F., Quadt, A.V., Roddick, J. C., Spiegel, W., 1995. Three Natural Zircon Standards for U-Th-Pb, Lu-Hf, Trace Element and REE Analyses. Geostandards Newsletter, 19, 1-23.

Willemant, B., Treuil, M., 1983. Comportement des éléments traces et majeurs dans la série alcaline du Velay ; comparaison avec la chaîne des Puys (Massif Central, France).

Wilson, M. and Downes, H. (1991). Tertiary-Quaternary extension-related alkaline magmatism in Western and Central Europe. Journal of Petrology 32, 811-849.

Wittig, N., Baker, J.A., Downes, H.,2006. Dating the mantle roots of young continental crust. Geology, 34, 237-240. 
741 the evolution of sub-continental lithospheric mantle, French Massif Central. Geochimica et 742 CosmochimicaActa, 71, 1290-1311.

Xu, Y.-G, Menzies, M.A., Bodinier, J.-L., Bedini, R.M., Vroon, P., Mercier, J.-C.,

744 1998. Melt percolation and reaction atop a plume: evidence from the poikiloblastic peridotite

745 xenoliths from Borée (Massif Central, France). Contribution to Mineralogy and 746 petrology,132, 65-84.

$748 \mathrm{Nd}$ isotopic characteristics and pressure-temperature estimates of mantle xenoliths from the

749 French Massif Central: evidence for melting and multiple metasomatism by silicate-rich 750 carbonatite and asthenospheric melts. From: Coltorti, M., Downes, H., Grégoire, M. \& 751 O'Reilly, S. Y. (eds) Petrological Evolution of the European Lithospheric Mantle. Geological 752 Society, London, Special Publications, 337, 153-175. deformation, equilibration temperatures, REE and radiogenic isotopes in mantle xenoliths (Ray Pic, Massif Central, France): an example of plume-lithosphere interaction? Contribution to Mineralogy and petrology, 127, 187-203.

Figure Captions:

760 Figure 1. Geological sketch map of the sampled area. 1: Variscan basement; 2: Cenozoic 761 grabens and sedimentary basins; 3: Cenozoic and Quaternary volcanism; blue square: sampled 762 area. 
764 Figure 2. a: $\mathrm{FeO}_{\mathrm{t}}$ vs. $\mathrm{TiO}_{2}$ diagram (weight \%) displaying the chemical composition of the 765 clinopyroxenes from the samples. b: $\mathrm{FeO}_{\mathrm{t}}$ vs. $\mathrm{SiO}_{2}$ diagram (weight \%) displaying the 766 chemical composition of the orthopyroxenes from the samples. In both diagrams, the light and 767 dark gray arrays represent typical compositions of these minerals in granulite (Leyreloup, 768 1973) and mantle xenoliths (Chazot, unpublished data) from the Massif Central, respectively.

Figure 3. Scanning Electron Microscope and binocular microscope images of the zircon crystals; A: subhedral zircons megacrysts from ESP-2 sample stream; B: fine oscillatory 772 zoning parallel to the zircon faces (ESP-2); C: euhedral zircon crystal from the lava flow 773 (ESP-1); D: sector-zoned and euhedralzircon crystal from the lava flow (ESP-1) partly 774 outlined by a fine alteration rim; E and F: sector zoned and rounded Pliocene zircons from the lava flow (ESP-1); G: oscillatory zoned and rounded Permian zircon from the lava flow (ESP1), partly outlined by a fine alteration rim; $\mathrm{H}$ : inherited core in a Permian rounded zircon from 777 the lava flow (ESP-1).

Figure 4. Tera and Wasserburg $(1972){ }^{238} \mathrm{U} /{ }^{206} \mathrm{~Pb}$ vs. ${ }^{207} \mathrm{~Pb} /{ }^{206} \mathrm{~Pb}$ diagrams of the dated samples A: alluvium deposit from Les Brus stream (ESP-2), mugearite lava flow (ESP-1) B:

781 Pliocene zircons and C: Permian zircons.

Figure 5. Hf-isotope evolution versus time diagram for zircons of the alluvium (blue circles) and of the mugearite lava flow (red circles).

786 Figure 6. Sm-Nd isochron diagram for mantle clinopyroxenes from various volcanic centres of the Massif Central (see text for references). 
Tables content:

790

791 Table 1. Major and trace element content of the ESP-1 mugearite sample.

792

793 Table 2. Zircon U-Th-Pb data from the dated samples obtained by in situ Laser Ablation ICP794 MS.

795 Supplementary Table S1. Detail of analytical conditions for In situ U-Th-Pb and Lu-Hf 796 isotope analysis.

797

798 Supplementary Table S2. Lu-Hf isotope data obtained by in situ Laser Ablation MC-ICP799 MS on synthetic zircons doped with hafnium and rare earth elements (Fischer et al., 2011b).

800

801 Supplementary Table S3. Chemical composition of minerals of the alluvium and mugearite 802 sample.

803

804 Supplementary Table S4. Zircon Lu-Hf isotope data obtained by in situ Laser Ablation MC805 ICP-MS.

806 